\title{
Ganglion cell tumours in the sella turcica in close morphological connection with pituitary adenomas
}

\author{
Ewa Matyja ${ }^{1,2}$, Maria Maksymowicz ${ }^{3}$, Wiesława Grajkowska ${ }^{4,5}$, Grzegorz Zieliński $^{6}$, Jacek Kunicki², Wiesław Bonicki², \\ Przemysław Witek ${ }^{7}$, Ewa Naganska ${ }^{4}$ \\ ${ }^{1}$ Mossakowski Medical Research Centre, Polish Academy of Sciences, Warsaw, ${ }^{2}$ Department of Neurosurgery, M. Sklodowska-Curie \\ Memorial Cancer Centre and Institute of Oncology, Warsaw, ${ }^{3}$ Department of Pathology and Laboratory Diagnostic, M. Sklodowska-Curie \\ Memorial Cancer Center and Institute of Oncology, Warsaw, ${ }^{4}$ Department of Experimental and Clinical Neuropathology, Mossakowski \\ Medical Research Centre, Polish Academy of Sciences, Warsaw, ${ }^{5}$ Department of Pathology, The Children's Memorial Health Institute, \\ Warsaw, ${ }^{6}$ Department of Neurosurgery, Military Institute of Medicine, Warsaw, ${ }^{7}$ Department of Endocrinology and Isotope Therapy, \\ Military Institute of Medicine, Warsaw, Poland
}

DOI: $10.5114 /$ fn. 2015.54421

\begin{abstract}
Ganglion cell tumours in the sellar region are uncommon. They are usually associated with pituitary adenomas, while isolated ganglion cell neoplasms are extremely rare. We report the clinicopathological studies of five cases diagnosed as ganglion cell tumours located in the intrasellar region: four mixed/collision tumours composed of gangliocytoma and pituitary adenoma, and one isolated ganglioglioma unrelated to adenoma. Clinically, two patients presented with acromegaly, while three others were initially diagnosed as non-functioning adenomas. In four cases, the histopathological examination of surgical specimens revealed intermixed lesions composed of pituitary adenoma and ganglion cell elements. The adenomas appeared to secrete growth hormone. Electron microscopy enabled identification of the sparsely granulated somatotroph cells. Neoplastic neuronal lesions were composed of mature ganglion cells, including binucleate or multinucleate cells. In all cases, boundaries between adenomatous and gangliocytic components were not clearly demarcated, and numerous gangliocytic cells were closely intermingled with adenomatous tissue. One case lacked endocrine symptoms, and no pituitary adenoma was identified in the surgically excised material; it was finally diagnosed as low-grade ganglioglioma. The etiopathogenesis of ganglion cell neoplasms in the sellar region is not clearly defined. Our study revealed that if ganglion cell neoplasms were combined with adenoma, both neoplastic components were closely related to each other, and numerous neuronal elements were strictly intermingled with adenoma cells. Such a tissue pattern indicates that these neoplastic changes, including their common respective etiopathogeneses, are closely related. The identification of both components in sellar regions may have some nosological implications.
\end{abstract}

Key words: ganglion cell tumour, gangliocytoma, ganglioglioma, sellar tumours, pituitary adenoma. 


\section{Introduction}

Gangliocytic neoplasms in the sella turcica and parasellar region are uncommon. Ganglion cell tumours in this location are usually associated with functioning or nonfunctioning pituitary adenomas or pituitary cell hyperplasia. Such neoplasms occur without evidence of adjacent adenoma only occasionally. The majority of ganglion cell tumours appear in association with growth hormone-secreting pituitary adenoma presenting with acromegaly $[2,4-6,12,17-19,23,25,32,38,40,42]$. They appear less often with adrenocorticotropic hormone-producing adenomas with clinical presentation of Cushing's disease $[25,36,40]$.

We present the clinicopathological features of five cases of intrasellar ganglion cell tumours: four mixed/collision tumours composed of gangliocytoma and pituitary adenoma, and one isolated ganglioglioma. Clinically, two patients presented with acromegaly, while three others were initially diagnosed with non-functioning adenomas.

\section{Material and methods}

The biopsy tissues from neurosurgery procedure were fixed in $10 \%$ formalin, embedded in paraffin and stained with hematoxylin and eosin (H\&E). Immunohistochemical staining was performed on paraffin-embedded specimens, according to the labelled EnVision Flex Visualization System (Dako, K8000) with DAB as chromogen, using antibodies against anterior pituitary hormones: prolactin (PRL, $1: 200)$, growth hormone $(\mathrm{GH}, 1: 500)$, adrenocorticotrophic hormone (ACTH, $1: 500)$, thyroid-stimulating hormone ( $\beta-\mathrm{TSH}, 1: 500)$, follicle-stimulating hormone $(\beta-\mathrm{FSH}, 1: 500)$, luteinizing hormone $(\beta-\mathrm{LH}$, $1: 500)$ all antibodies from Thermo Scientific Lab Vision Corp., andglycoprotein $\alpha$-subunit $(1: 100)$ from Novocastra. The antibodies against CAM5,2 from Cell Marque and: cytokeratins AE1/AE3 (CK), chromogranin A, glial fibrillary acidic protein (GFAP), S100 protein, synaptophysin, neurofilaments (NF) and Ki-67 (MIB-1) from Dako (all antibodies ready to use) were also used.

For electron microscopic study, the tissue was fixed in $2.5 \%$ glutaraldehyde, postfixed in $1 \%$ osmium tetroxide, dehydrated in graded alcohols and embedded in Epon 812. Ultrathin sections were counterstained with uranyl acetate and lead citrate and examined in a Philips CM 120 BioTWIN electron microscope.

\section{Report of cases \\ Case 1}

A 51-year-old woman who presented with acromegaly was admitted to the Department of Neurosurgery. Changes in this patient's facial features has developed slowly over the last several years, and included nasal dysmorphism and skin changes. Growth in the acral parts of limbs had been observed, with increases noted in her foot and finger sizes. The patient had been complaining of headaches, significant perspiration, and fatigue for many years. She denied any visual problems. She also had diabetes mellitus and menstrual irregularities. There was no family history of pituitary or brain tumours. Magnetic resonance imaging (MRI) of the brain revealed a homogenously enhanced, large pituitary mass with sellar floor destruction and suprasellar and infrasellar extension (Fig. 1A-C). The tumour diameter was approximately $2.5 \mathrm{~cm}$. Tumour growth had resulted in mild compression of the optic chiasm and invasion of the right cavernous sinus $(\text { Knosp III })^{\circ}$. The pituitary gland appeared normal, but was displaced to the medial wall of the left cavernous sinus and diaphragm sellae. Endocrine laboratory tests revealed elevated $\mathrm{GH}(8.1 \mu \mathrm{g} / \mathrm{ml})$. The PRL level, measured several times, ranged from 57.3 to $189.1 \mathrm{ng} / \mathrm{ml} ; \beta$-TSH and free thyroxine (free T4) were $0.119 \mathrm{mIU} / \mathrm{l}$ and $11.88 \mathrm{pmol} / \mathrm{l}$, respectively; serum cortisol was $85.9 \mathrm{ng} / \mathrm{ml}$ at $8: 00 \mathrm{AM}$ and $27.3 \mathrm{ng} / \mathrm{ml}$ at 8:00 PM. The patient received 8 months of pretreatment with somatostatin analogue (sandostatin, LAR $30 \mathrm{mg}$ ), which resulted in tumour regression on neuroimaging studies. Surgery was conducted using a trans-sphenoidal microsurgical approach with tumour resection. Transitional postoperative hypopituitarism was observed. At follow-up, this patient had persistent acromegaly caused by tumour remnants in the right cavernous sinus. She was referred for a radiosurgical procedure.

\section{Histopathology}

Histological examination of the resected specimens revealed two different neoplastic components: pituitary adenoma and ganglion cell neoplasm (Fig. 2A). The ganglion cell lesion was composed of large neoplastic neuronal cells scattered in a fibrillar, eosinophilic background (Fig. 2B). Numerous ganglion cells exhibited irregular cytoplasmic outlines 

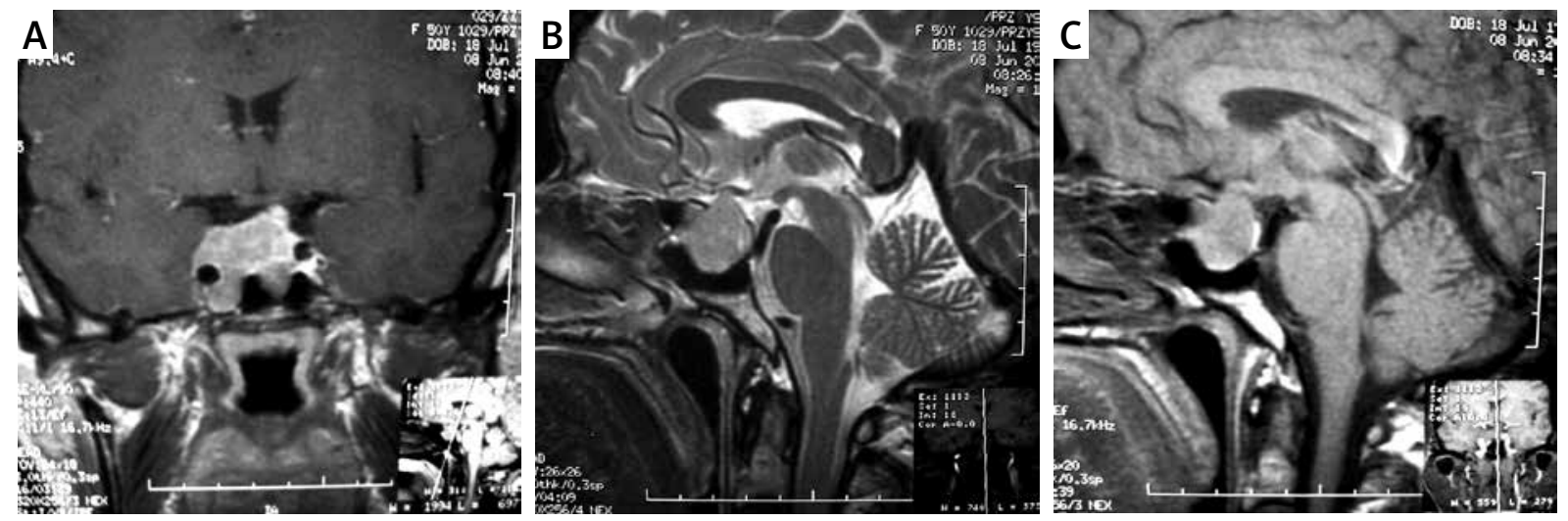

Fig. 1. Case 1: A) A coronal, post-contrast, T1-weighted MRI depicts an invasive sellar mass with moderate heterogeneous enhancement and invasion of the right cavernous sinus. B) A sagittal T2-weighted MRI shows an isointense tumour with sellar enlargement, moderate suprasellar extension, and slight compression of the optic chiasm. C) A sagittal, post-contrast, T1-weighted MRI depicts the sellar tumour with moderate enhancement and remnants of pituitary.

and aggregates of Nissl granules at the cell body periphery. Immunohistochemistry revealed diffuse immunoreactivity for NF (Fig. 2C) and intense synaptophysin expression (Fig. 2D). The lesion lacked any astroglial component positive for GFAP.

Immunostaining for pituitary hormones demonstrated GH-positive adenoma cells in the adenomatous part (Fig. 2E). The intermingled neurons themselves did not express GH immunoreactivity. Other pituitary hormones were not detected. The pituitary tumour cells were immunopositive for $\mathrm{CK}$, chromogranin A, and synaptophysin. The boundaries between adenomatous and gangliocytic components were not clearly demarcated, and clusters of small adenoma cells were intermingled with neuronal elements.

Ultrastructural features documented a sparsely granulated somatotroph adenoma (SG-GH) composed of medium-sized, round cells. Some cells contained typical globular fibrous bodies of intermediate filaments and sparse, small, electron-dense secretory granules (Fig. 2F).

The final histopathological diagnosis was established as sparsely granulated somatotroph pituitary adenoma combined with gangliocytoma.

\section{Case 2}

A 59-year-old man with a history of headaches and visual disturbances for the past few weeks was admitted to the Department of Neurosurgery. The patient did not present clinical symptoms typical of acromegaly or Cushing's syndrome. His levels of PRL and other pituitary hormones were within normal ranges. An MRI revealed a large sellar-suprasellar mass with moderate heterogenous enhancement after gadolinium administration. On T1-weighted sequences, a rim of compressed anterior pituitary tissue was observed. The tumour caused enlargement of the sella turcica and invaded the left cavernous sinus and sellar floor, with submucosal extension to the left sphenoid sinus (Fig. 3A,B). Its maximal cranio-caudal diameter was $36 \mathrm{~mm}$. The clinical diagnosis was a nonfunctioning invasive macroadenoma.

The patient underwent two consecutive surgeries with an endoscopic trans-sphenoidal approach. The initial surgery was a subtotal resection that left tumour remnants invading the left cavernous sinus and the diaphragm of the sella. Intraoperatively, the tumour displayed a biphasic appearance, with predominant yellow-whitish fibrous tissue and an admixture of pink-white foci; it resembled a typical intraoperative view of pituitary adenoma. The procedure was ceased because of bradycardia and suspicion of acute coronary syndrome. The postoperative course was uneventful, with significant visual improvement.

Eight months later, the residual sellar tumour was resected through the same operating access. The sellar floor was reconstructed with an autologous fat tissue graft, titanium micro-mesh, and fibrin glue. The postoperative MRI revealed minimal tissue remnants within the left cavernous sinus. The postoperative course was uneventful, with no visual 

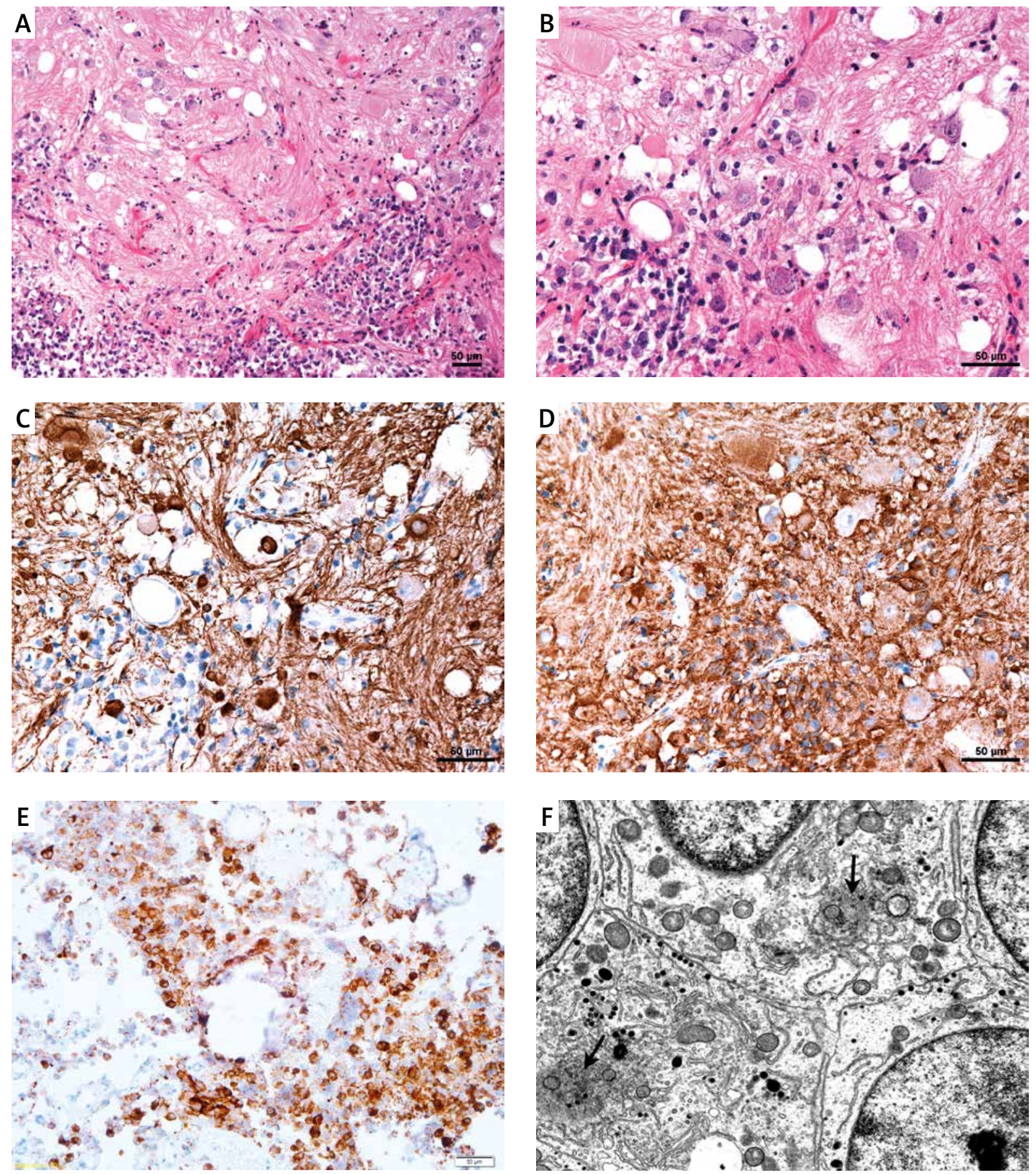

Fig. 2. Case 1: A) This sellar tumour is composed of small, round, adenoma cells and a lesion of gangliocytic cells with a fibrillar, eosinophilic background, H\&E. B) Large neoplastic ganglion cells are closely intermixed with adenoma cells, H\&E. Note the gangliocytic part of the tumour exhibits strong expression of NF (C) and synaptophysin (D). E) Adenoma cells are immunoreactive for $\mathrm{GH}$. F) Ultrastructural features of sparsely granulated somatotroph adenoma with polygonal cells, containing abundant cytoplasm and characteristic fibrous bodies (arrows). Secretory granules are sparse and small. Original magnification 9700x. 

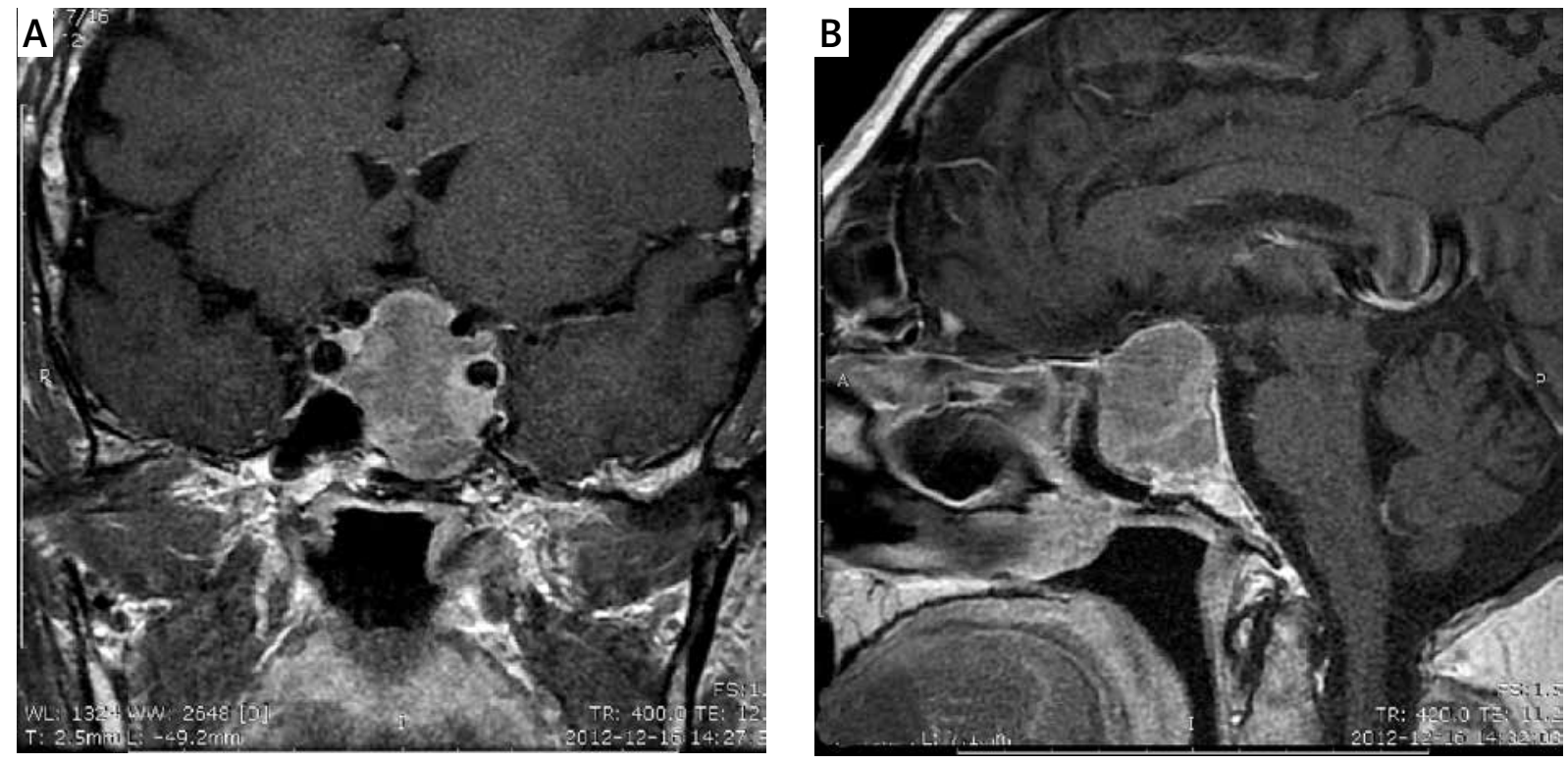

Fig. 3. Case 2: Coronal post-contrast (A) and axial T1-weighted (B) MRI reveal a hyperintense tumour of the sellar region with erosion of the sellar floor, invasion of the left cavernous sinus, and moderate suprasellar extension with optic chiasm compression.

symptoms. The $\mathrm{GH}$ level was below $1 \mathrm{ng} / \mathrm{ml}$, with some minimal elevation of insulin-like growth factor 1 (363 ng/ml; N: 144-286). The patient did not require any hormone replacement therapy.

\section{Histopathology}

At both surgeries, the tumours were composed of pituitary adenoma combined with a ganglion cell component (Fig. 4A). The large part of the lesion was composed of clusters of randomly distributed ganglionic cells exhibiting abundant cytoplasm, large vesicular nuclei with prominent nucleoli, and aggregates of Nissl granules. Binucleate or multinucleate neoplastic neuronal cells were present. Immunohistochemistry revealed intense synaptophysin expression outlining the cell borders (Fig. 4B) and $\mathrm{NF}$ in the ganglion cell bodies and their processes (Fig. 4C). The gangliocytic component correlated closely with pituitary adenoma, and numerous ganglion cells were intermixed with adenomatous tissue. The pituitary adenoma cells were strongly positive for chromogranin A and cytokeratin. The adenomatous cells revealed $\mathrm{GH}$ immunoexpression (Fig. 4D), but were negative for other anterior pituitary hormones.

Electron microscopy revealed ultrastructural features of sparsely granulated somatotroph adenoma, composed of round, medium-sized cells with typical cytoplasmic fibrous bodies (Fig. 4E). The ganglion cells were characterized by the presence of a large nucleus or nuclei, with prominent nucleoli. We also observed binucleate neuronal cells (Fig. 4F). The cytoplasm of neuronal cells contained abundant mitochondria, well-developed endoplasmic reticulum, neurofilaments, and dense core neurosecretory granules. The neuronal processes contained microtubules and dense core neurosecretory granules. Ultrastructural studies provided evidence of a close relationship between neuronal and adenomatous elements. Silent sparsely granulated somatotroph pituitary adenoma and gangliocytoma was the final pathological diagnosis.

\section{Case 3}

A 58-year-old, post-menopausal woman with a 3-month history of headache and diplopia was admitted to the Department of Neurosurgery. At admission, neuro-ophthalmological examination revealed a decrease of visual acuity to 0.9 in both eyes and diplopia with not restriction of the visual field. There was a limitation of abduction on the right side. The color and shape of optic discs were normal. Apart from the visual impairment, the neurological examination did not reveal any focal 

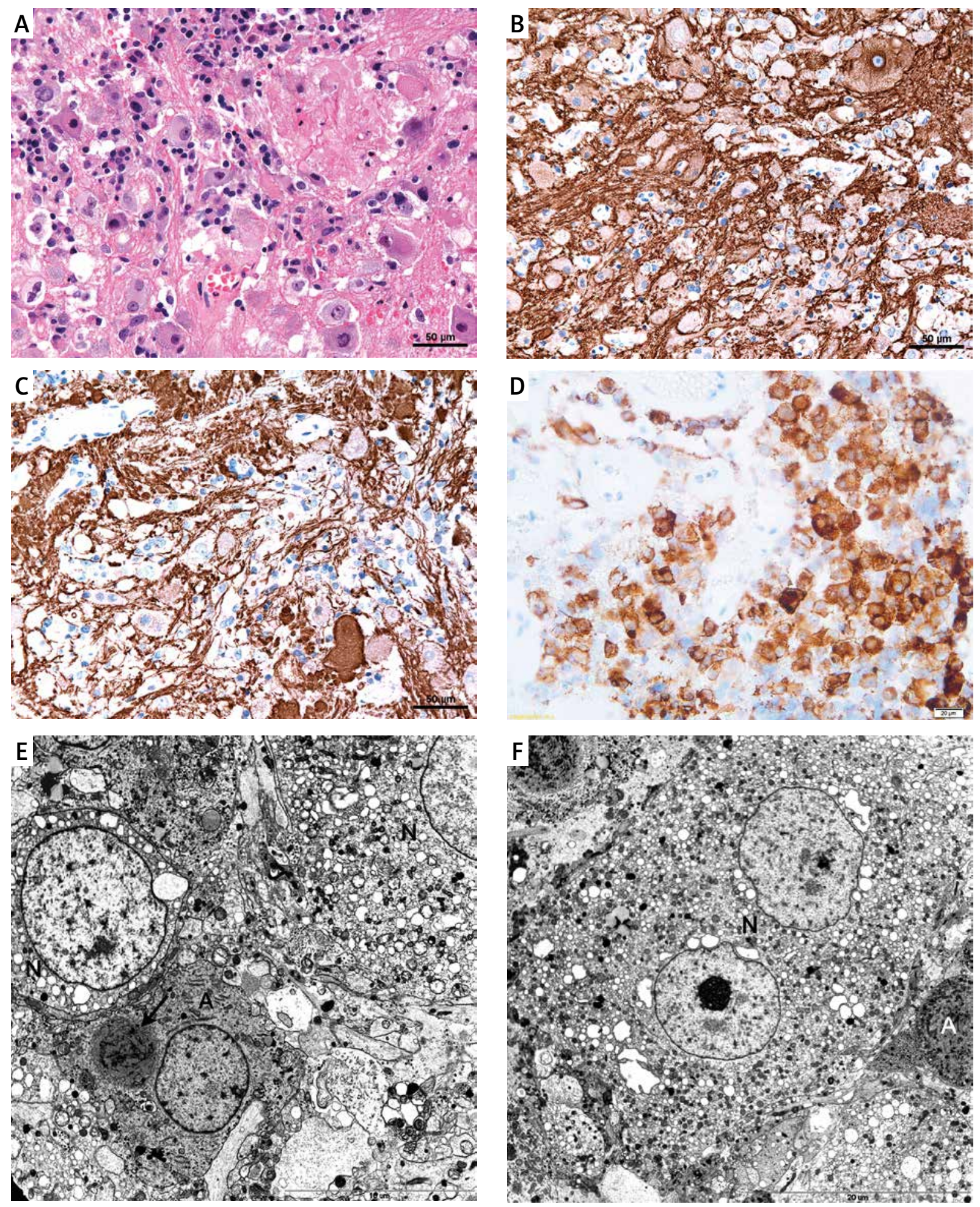

Fig. 4. Case 2: A) A mixed sellar tumour composed of an adenomatous component and large ganglion cells, H\&E. B) The gangliocytic component, with strong immunostaining for synaptophysin. C) Ganglion cells and dense neuronal processes are strongly immunoreactive for NF. D) GH-secreting adenoma cells. E) Ultrastructure of gangliocytoma admixed with sparsely granulated somatotroph adenoma. Large ganglion cells $(\mathrm{N})$ with abundant cytoplasm are surrounded by bands of axons and polygonal cells of somatotroph adenoma, with characteristic fibrous bodies (arrow); original magnification 4200×. F) The large binucleate neuronal cell $(\mathrm{N})$ with a prominent nucleolus and abundant cytoplasm, contains numerous mitochondria, vacuoles, and neurofilaments, as well as small adenomatous cells (A); original magnification 2500x. 
Table I. Preoperative hormonal results (Case 3)

\begin{tabular}{|cccccccc|}
\hline GH & IGF-1 & TSH & fT4 & PRL & FSH & LH & Cortisol \\
\hline $0.93 \mu \mathrm{g} / \mathrm{l}$ & $197 \mu \mathrm{g} / \mathrm{ml}$ & $0.233 \mu \mathrm{lU} / \mathrm{ml}$ & $19.42 \mathrm{pmol} / \mathrm{l}$ & $6.9 \mathrm{ng} / \mathrm{ml}$ & $34.33 \mathrm{lU} / \mathrm{l}$ & $15.05 \mathrm{lU} / \mathrm{l}$ & $16.6 \mu \mathrm{gg} / \mathrm{dl}$ \\
\hline
\end{tabular}

deficits of cranial nerves. There were no symptoms of raised intracranial pressure. Other than obesity, the patient did not present typical Cushing's syndrome features. Acromegaly was not observed. Pituitary hormone levels were within normal limits, and there were no signs of diabetes insipidus (Table I).

MRI revealed an aggressive pituitary tumour measuring $14 \times 13 \times 15 \mathrm{~mm}$, with right cavernous sinus invasion, partial encasement of the right cavernous carotid artery, and sellar floor erosion (Fig. 5A,B). Microsurgery was performed using a trans-sphenoidal approach. The tumour was removed subtotally owing to invasion of the cavernous sinus. The pituitary gland was displaced to the left side of the sella. The postoperative course was uneventful. Based on the patient's postoperative early morning serum cortisol level, insufficiency of the adrenal cortex was excluded. There were no postoperative indications of diabetes insipidus or water-electrolyte disturbance (e.g., hyponatremia). This patient was discharged from the Neuro- surgical Department in good general condition and transferred to the outpatient clinic.

\section{Histopathology}

Microscopically distinct neoplastic components composed of pituitary adenoma and ganglion cell neoplasm were found (Fig. 6A). The gangliocytic component was composed of pure neoplastic ganglion cells distributed within a neuropil-like background, without any glial component. The majority of ganglion neoplastic cells were large, some of them binucleate or multinucleate, and were closely intermixed with small adenoma cells (Fig. 6B). Immunohistochemistry revealed fairy dense granular reactivity for synaptophysin (Fig. 6C) and reactivity for NF. The adenomatous part of the tumour was composed of GH-positive adenoma cells (Fig. 6D). There was no immune reactivity against any other pituitary hormones. The pituitary tumour cells expressed chromogranin A, and synaptophysin. Electron microscopy was not performed but immunoreaction for Cam
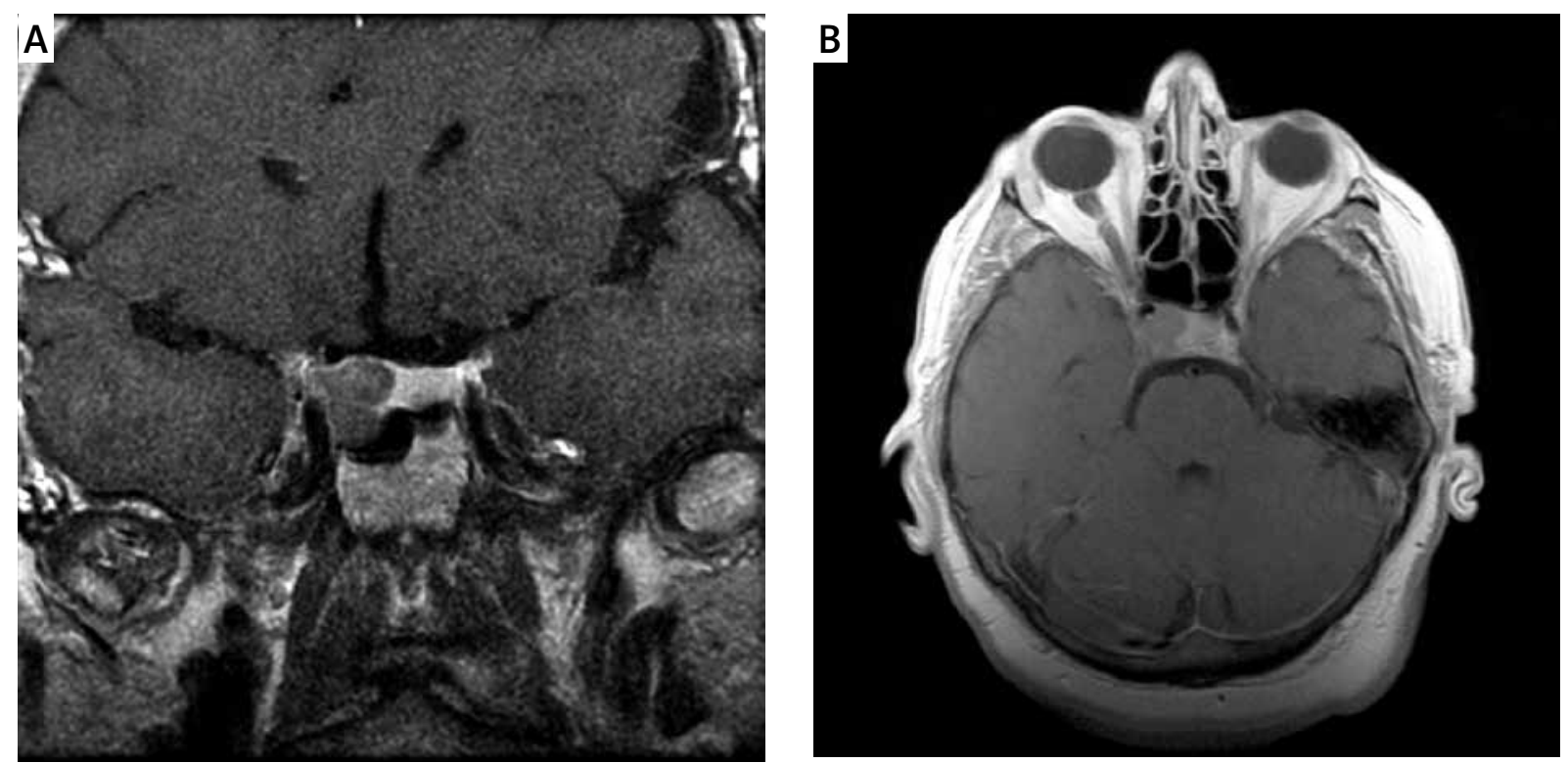

Fig. 5. Case 3: Coronal (A) and axial (B) T1-weighted, post-Gd-DTPA MRI depict an aggressive pituitary tumour with invasion of the right cavernous sinus (Knosp $\mathrm{II}^{\circ}$ ), partial encasement of the right cavernous carotid artery, and sellar floor erosion. 

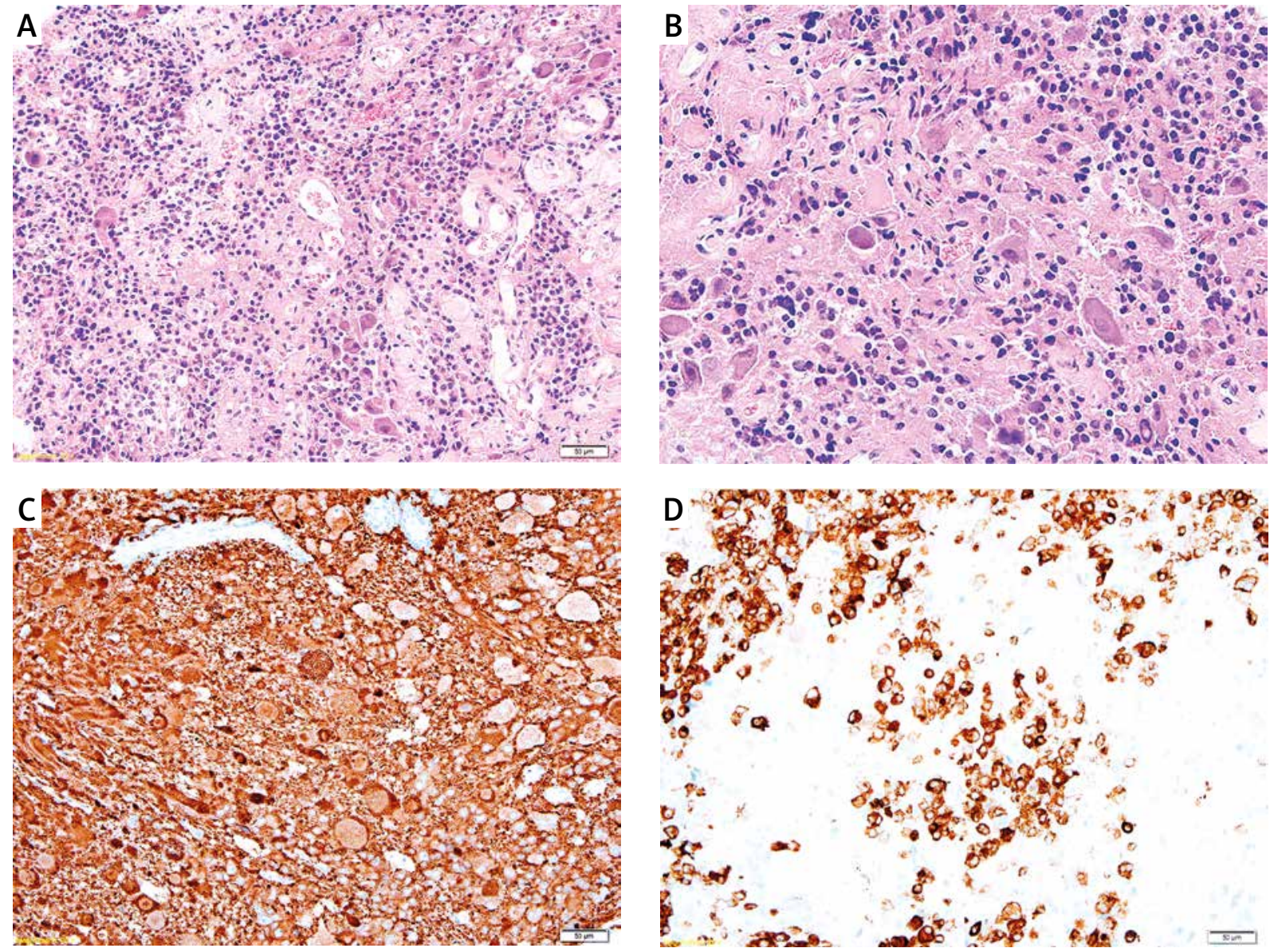

Fig. 6. Case 3: (A) A mixed sellar lesion composed of gangliocytic cells and adenoma, H\&E. B) The majority of ganglion tumour cells were large and closely intermixed with small adenoma cells, H\&E. C) Dense granular immunoreactivity for synaptophysin. D) GH-positive adenoma cells in the adenomatous part of the tumour.

5.2 supported the diagnosis of sparsely granulated somatotroph pituitary adenoma.

The final histopathological diagnosis was silent sparsely granulated somatotroph pituitary adenoma and gangliocytoma.

\section{Case 4}

A 63-year-old woman was admitted to the Department of Neurosurgery with typical clinical features of acromegaly lasting 6 years. Her presenting symptoms were progressive headaches and sleep apnea syndrome. The patient was under general medical care because of arterial hypertension and diabetes mellitus. Neurological examination showed no impairment of visual acuity or visual fields. The function of other cranial nerves was also intact. Fundoscopic examination revealed no optic nerve atro- phy. The patient had no family history of pituitary adenoma or multiple endocrine neoplasia. Endocrine investigation revealed elevated basal serum levels of $\mathrm{GH}$ and somatomedin-C, with an abnormal oral glucose tolerance test. The serum levels of other pituitary hormones were within normal limits (Table II).

$\mathrm{MRI}$ of the sellar region revealed a homogenic tumour mass $(12 \times 15 \times 16 \mathrm{~mm})$ with intrasellar extension and invasion of the left cavernous sinus $\left(\right.$ Knosp $\mathrm{I}^{\circ}$ ) on coronal and sagittal T1-weighted images before and after the administration of Gd-DTPA (Fig. 7A,B).

The patient underwent trans-sphenoidal surgery. During the procedure, a yellowish, fibrous, compact tumour was separated from the pituitary gland and completely excised. There were no signs of cavernous sinus invasion. The postoperative period was 
Table II. Preoperative hormonal results (Case 4)

\begin{tabular}{|c|c|c|c|c|c|c|c|c|}
\hline $\mathrm{GH}$ & IGF-1 & IGF BP3 & TSH & fT4 & PRL & FSH & LH & Cortisol \\
\hline $\begin{array}{c}3.88 \mu \mathrm{g} / \mathrm{l} \\
60^{\prime} \\
5.14 \mu \mathrm{g} / \mathrm{l} \\
120^{\prime} \\
3.81 \mu \mathrm{g} / \mathrm{l}\end{array}$ & $976 \mathrm{ng} / \mathrm{ml}$ & $9.40 \mu \mathrm{g} / \mathrm{ml}$ & $1.05 \mu \mathrm{lU} / \mathrm{ml}$ & $20.41 \mathrm{pmol} / \mathrm{l}$ & $5.67 \mathrm{ng} / \mathrm{ml}$ & $86.21 \mathrm{IU} / \mathrm{I}$ & $21.11 \mathrm{IU} / \mathrm{I}$ & $\begin{array}{c}8.00- \\
8.26 \mu \mathrm{g} / \mathrm{dl} \\
20.00- \\
1.81 \mu \mathrm{g} / \mathrm{dl}\end{array}$ \\
\hline
\end{tabular}
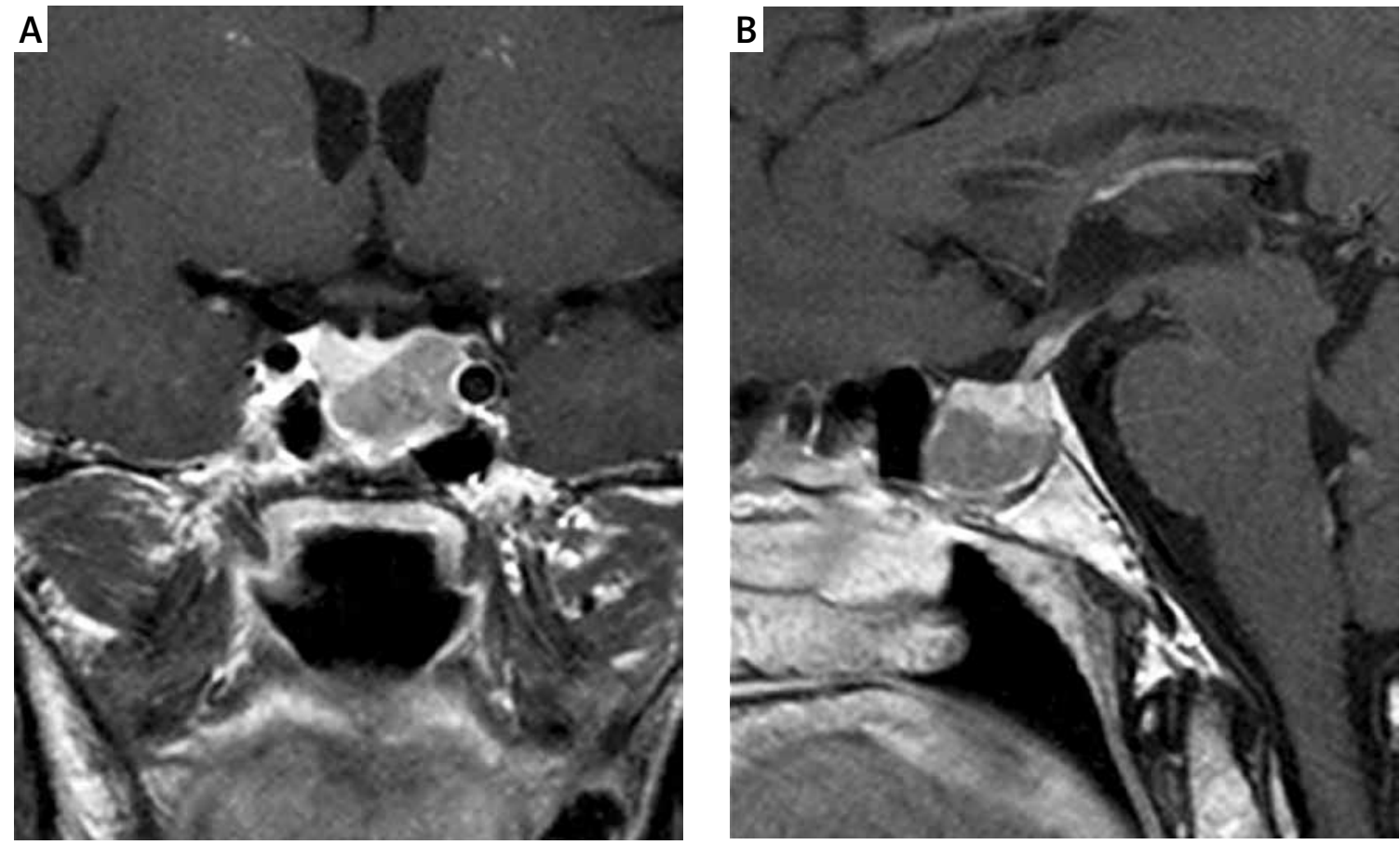

Fig. 7. Case 4: MRI of the sellar region. Coronal (A) and sagittal (B) T1-weighted images before and after Gd-DTPA administration reveal a homogenic tumour mass with intrasellar extension and invasion of the left cavernous sinus $\left(\right.$ Knosp I ${ }^{\circ}$.

uneventful. There were no postoperative indications of diabetes insipidus or water-electrolyte disturbance (e.g., hyponatremia). The patient was discharged from the Neurosurgical Department in good general condition and transferred to the endocrinological outpatient clinic.

\section{Histopathology}

The tumour comprised mixed pituitary adenoma and gangliocytoma (Fig. 8A). Both neoplastic components were closely intermingled. The gangliocytic part exhibited clusters of large neuronal cells within a fibrillar background. Large binucleate or multinucleate ganglion cells were often seen (Fig. 8B). Immunohistochemistry documented strong NF expression (Fig. 8C). In the adenomatous part of the lesion, a few small (probably adenoma) cells and short pro- cesses also exhibited NF immune reactivity (Fig. 8D). Both tumour components strongly expressed synaptophysin (Fig. 8E). Tumour cells were negative for GFAP and S-100 protein. The pituitary adenoma cells were immunoreactive for GH (Fig. 8F), and negative for other anterior pituitary hormones. The Ki-67 labeling index was low.

Electron microscopy revealed ultrastructural features of sparsely granulated somatotroph adenoma combined with the ganglion cell component. The final histopathological diagnosis was sparsely granulated somatotroph pituitary adenoma combined with gangliocytoma.

\section{Case 5}

A 26-year-old man was referred to the Department of Neurosurgery with persistent, distending 

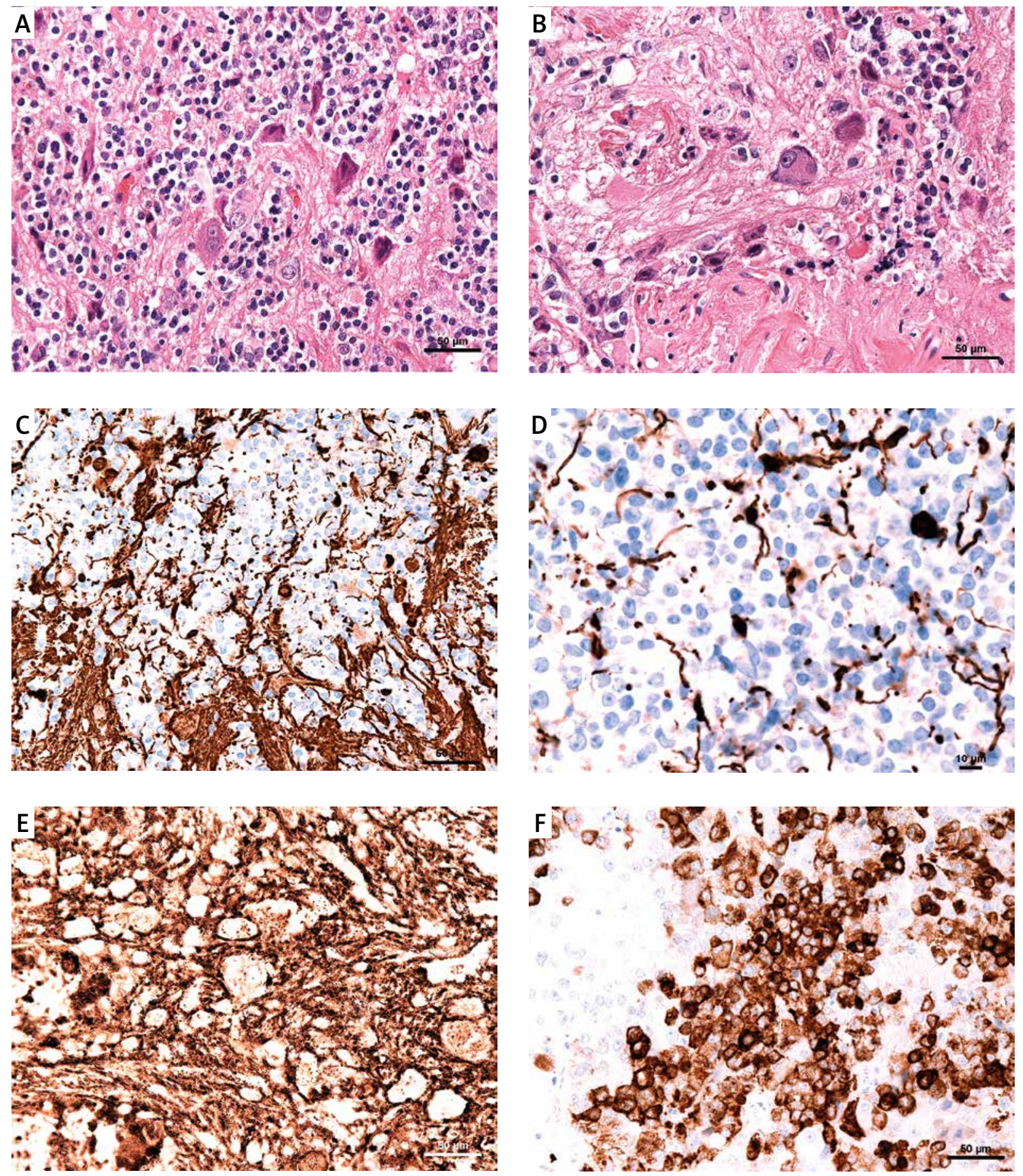

Fig. 8. Case 4: A) A mixed sellar lesion composed of gangliocytic cells intermingled with adenoma, $H \& E$. B) Large ganglion cells, including binucleate or trinucleate cells, H\&E. C) Immunoreactivity for NF. D) A few small, likely adenoma cells and short processes exhibiting NF immunoreactivity. E) Strong synaptophysin expression. F) Immunoreactivity for $\mathrm{GH}$ in pituitary adenoma cells. 
headache and dizziness that had lasted approximately 3 months prior to admission. The patient had suffered from progressive visual impairment for the last 6 weeks before admission. Two weeks prior to admission, MRI had revealed a skull base tumour with extension of the lateral ventricles. Coronal (Fig. 9A) and sagittal (Fig. 9C) T1-weighted MRI after Gd-DTPA and coronal T2-weighted MRI (Fig. 9B) revealed a giant, invasive skull base tumour measuring $42 \times 29 \times 49 \mathrm{~mm}$. The mass lesion originated from the sella turcica, with invasion of the hypothalamus and brain stem, encasement of the arteries of the circle of Willis, and compression of the pituitary gland. Treatment with steroids (dexamethasone $12 \mathrm{mg}$ p.o. daily) was initiated. After admission, the patient was conscious, but confused and drowsy. The ophthalmological examination revealed a decrease of visual acuity to 0.5 in both eyes, as well as bilateral temporal field restriction without diplopia. The optic discs were pale and without papilloedema. Neurological examination demonstrated no obvious clinical signs. We measured this patient's hormone levels in order to assess pituitary function, and the results confirmed secondary adrenal insufficiency. Anterior pituitary insufficiency was diagnosed based on the obtained results (Table III).
The patient underwent subtotal tumour resection through a right-side temporal craniotomy. In the course of this treatment, the visual abnormalities resolved, but third cranial nerve paresis occurred.

The postoperative control axial computed tomography scan revealed lateral ventricle extension. The patient's neurological state improved gradually after a ventriculo-peritoneal shunt was implanted. The patient was finally discharged on the $23^{\text {rd }}$ day of his hospital stay, and was administered replacement hormonal therapy (hydrocortisone, 30 mg once daily; levothyroxine supplementation, $100 \mu \mathrm{g} /$ day). Three months after surgery, the patient died during complementary radiotherapy.

\section{Histopathology}

Microscopically, the sellar lesion appeared to be a mixed glioneuronal tumour composed of large, often multipolar neurons of various size and neoplastic astroglial elements (Fig. 10A). The ganglion-like cells displayed conspicuous nucleus and abundant cytoplasm, with aggregated Nissl granules at the perikarion periphery. The glial component was composed of bipolar, elongated, pilocytic-like astroglial cells within a fibrillar background. The lesion lacked
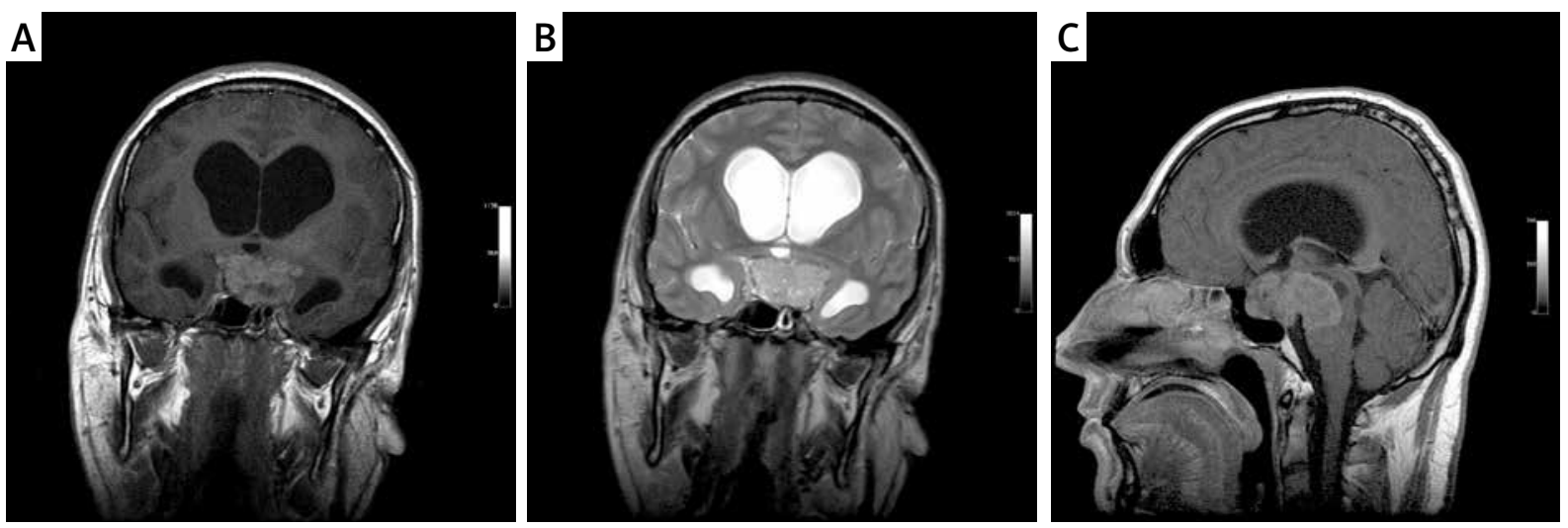

Fig. 9. Case 5: Coronal (A, B) and sagittal (C) T1-weighted MRI depict a homogenously enhanced, huge intrasellar and suprasellar mass with sellar floor destruction. Note the involvement of the optic chiasm, floor of the third ventricle, and midbrain, with compression of the aqueductus mesencephali and resultant hydrocephalus.

Table III. Preoperative hormonal results (Case 5)

\begin{tabular}{|cccccccc|}
\hline GH & ACTH & TSH & fT4 & PRL & FSH & LH & Testosterone \\
\hline $0.42 \mu \mathrm{g} / \mathrm{l}$ & $\begin{array}{c}7 \mathrm{pg} / \mathrm{ml} \\
\text { (during } \\
\text { steroids } \\
\text { therapy) }\end{array}$ & $0.93 \mu \mathrm{lU} / \mathrm{ml}$ & $6.21 \mathrm{pmol} / \mathrm{l}$ & $21 \mathrm{ng} / \mathrm{ml}$ & $1.2 \mathrm{lU} / \mathrm{l}$ & $0.93 \mathrm{lU} / \mathrm{l}$ & $0.41 \mathrm{ng} / \mathrm{ml}$ \\
& & & & & & & \\
\hline
\end{tabular}



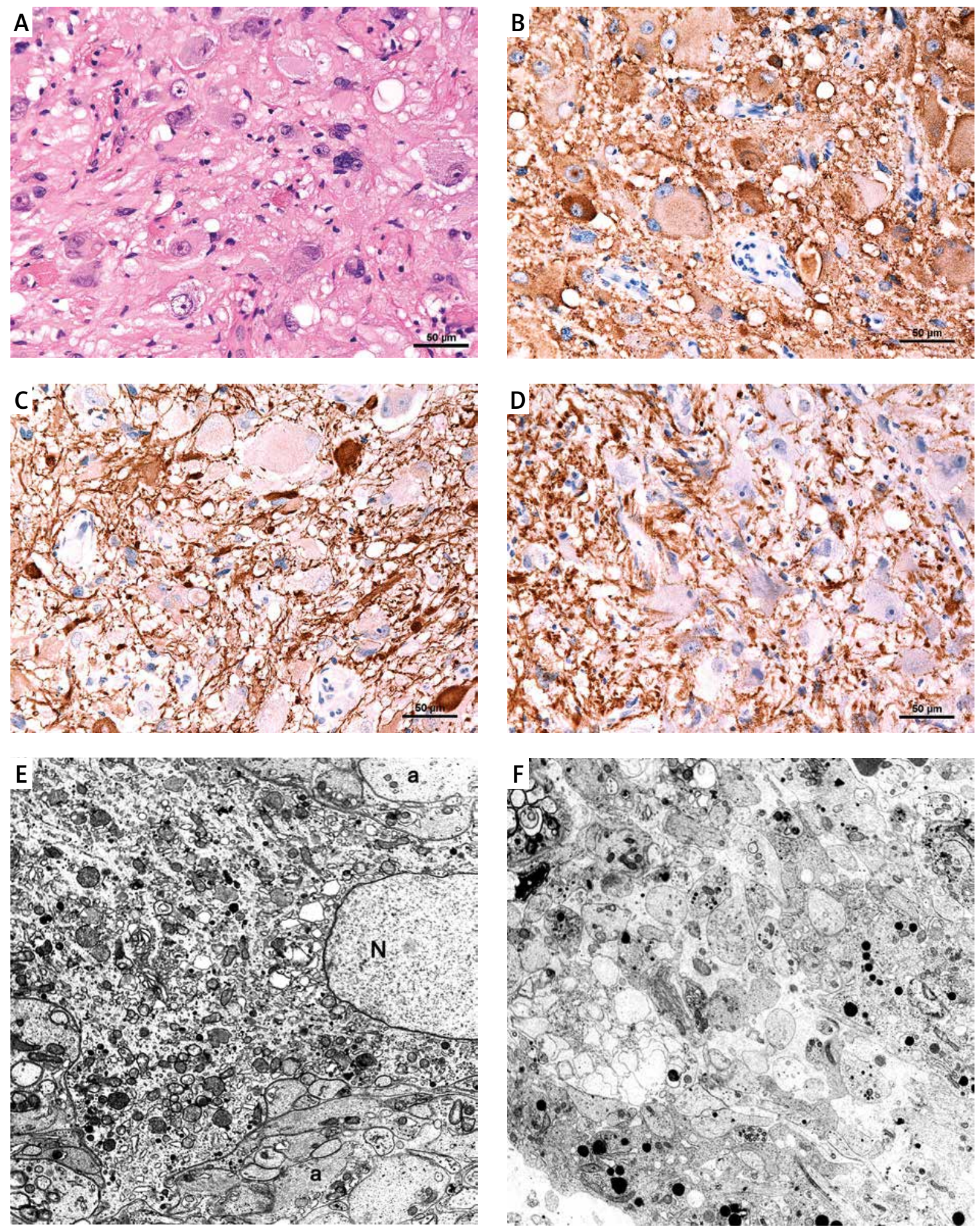

Fig. 10. Case 5: Ganglioglioma of the sellar region. A) Ganglion cells combined with neoplastic astrocytes, H\&E. B) Synaptophysin immunoreactivity at the surface of ganglion cells. C) NF expression in ganglion cell processes and cell bodies. D) GFAP-positive astroglial neoplastic cells surrounding immunonegative neuronal cells. E) Ultrastructure of a large ganglion cell $(\mathrm{N})$ with abundant cytoplasm filled with numerous organelles. Glial processes were identified in the surrounding neuropil. Original magnification 7400×. F) Neuropil with numerous neuronal and glial processes. Original magnification 4200x. 
mitotic figures and signs of vascular hyperplasia or necrosis. Immunohistochemistry supported the biphasic nature of tumours expressing of both neuronal and glial markers. The neuronal cells exhibited strong surface and/or cytoplasmic synaptophysin reactivity (Fig. 10B). The presence of NF was documented in ganglion cell bodies and neuronal processes (Fig. 10C). Astroglial cells were immunoreactive for GFAP (Fig. 10D) and S-100 protein. The Ki-67 labeling index was below $1 \%$. There was no adenomatous tissue or normal pituitary gland in the surgically excised material.

Ultrastructural studies revealed large ganglion cells with abundant cytoplasm filled with numerous organelles (Fig. 10E). Numerous neuronal and glial processes were identified in the surrounding neuropil (Fig. 10F). The histopathological diagnosis was established as a low-grade ganglioglioma, WHO GI.

\section{Discussion}

Various malignancies arise in the intrasellar or parasellar region, including pituitary adenomas, craniopharyngiomas, and glial and neuronal neoplasms. However, these tumours rarely occur together. The most common tumours of the sellar and suprasellar region are pituitary adenomas and craniopharyngiomas, which have occasionally been reported in collision $[15,20,33]$. Mixed pituitary adenomas and craniopharyngiomas usually display a close commixture of both neoplastic components. They are called "hybrid" cells and exhibit features of both pituitary adenoma and craniopharyngioma [15]. Such cells contain small, dense secretory granules, bundles of cytoplasmic filaments, and desmosomes.

Glial neoplasms, which are occasionally found in the sellar region, include pilocytic astrocytoma, diffuse astrocytoma, pilomyxoid astrocytoma, oligoastrocyto$\mathrm{ma}$, and mixed glio-neuronal tumours. The clinical presentation and imaging features of these lesions differ from those of craniopharyngiomas. These tumours can cause visual disturbances, GH deficiencies, cystic changes, and calcification [13]. However, glial neoplasms are only occasionally combined with pituitary adenomas.

The neurohypophysis is also a rare site of ganglion cell tumours. The majority of ganglionic tumours at this location occur in association with pituitary pathology; less often, they appear as isolated lesions. Sellar gangliocytomas may cause hyperse- cretion of pituitary hormone and enlargement of the sella turcica. Sometimes, they are separable from the pituitary gland, stalk, and hypothalamus, and may be successfully removed without further endocrine deficit [16]. Most sellar ganglion cell lesions are related to functioning or nonfunctioning pituitary adenomas or pituitary cell hyperplasia. However, independent of such relationship, they can cause a variety of clinical symptoms that reflect mass effect or their own endocrine activity. Occasionally, pure ganglion cell tumours are themselves hormonally active [35]. An unique case of ganglioglioma of the neurohypophysis associated with syndrome of inappropriate antidiuretic hormone secretion (SIADH) has been reported [14].

A few studies describing a larger series of cases with sellar ganglion cell tumours, classified as ganglioneuromas or gangliocytomas, have been published $[7,35,46]$. In earlier reports, the different terminology was used to describe ganglion cells lesions, including pituitary adenoma with neuronal choristoma (PANCH) [34,38,42,43], hypothalamic hamartomas, and hamartomatous gangliocytomas [22]. Such a diverse classification may cause nosological confusion. Typical pituitary gangliocytomas located within the sella turcica are not connected with hypothalamus, and the distinction between gangliocytoma and choristoma at a hypothalamic location is not reasonable [43].

Ganglion cell tumours, considered gangliocytomas and gangliogliomas, are usually benign, slow-growing neoplasms; they constitute only $0.4 \%$ of all central nervous system tumours and $1.3 \%$ of all brain tumours [28]. They are composed of mature ganglion cells with or without a glial component. Gangliocytomas of the pituitary gland are exceptionally rare and usually coexist with a pituitary adenoma, most commonly a $\mathrm{GH}$-secreting adenoma, with the clinical manifestation of acromegaly [4-6,12,17, $23,27,32,35,39,44,46]$; less often, they are associated with ACTH-producing adenomas, and present with Cushing's disease $[25,36,40]$.

Only in exceptional cases has the coexisting adenoma been endocrinologically silent. Occasionally, gangliocytic lesions of the pituitary gland arise without pituitary adenoma; however, these might themselves produce corticotrophin-releasing factor and display clinical signs of Cushing's disease $[3,8]$. Thus far, few cases of Cushing's syndrome associated 
with intrasellar ganglion cell lesions, including isolated ganglion lesions, have been described $[35,46]$.

Isolated sellar gangliocytoma without adenoma may also manifest as acromegaly (or, occasionally, diabetes insipidus or hypopituitarism). One case of mixed ACTH adenoma-gangliocytoma with an opportunistic infection has been described [10]. A very rare case of combined gangliocytoma and PRL-producing adenoma (prolactinoma) of the pituitary gland has also been reported $[9,30,45]$.

In the presented cases, the histopathological examination of surgical specimens from four patients (two cases of acromegaly and two cases of clinically nonfunctioning pituitary tumours) revealed pituitary adenomas closely intermingled with neoplastic ganglion cells. The adenomatous contribution appeared to be a GH-secreting adenoma on immunohistochemistry, and sparsely granulated somatotroph adenoma on electron microscopy. In all cases, the neuronal contribution was diagnosed as a purely gangliocytic lesion composed exclusively of groups of neoplastic mature ganglion cells. The two components were close together and in some places intermingled with each other. The close relationship of both neoplastic components suggests that they share a common origin. The neoplastic ganglion cells lacked pituitary hormone expression. The fifth case had no endocrine symptoms, and there was no adenoma or normal pituitary gland in the surgically excised material. The sellar lesion appeared to be a mixed glio-neuronal tumour composed of large, ganglioid, often multipolar neurons and neoplastic astroglial elements. Immunohistochemistry supported a biphasic pattern of neoplastic tissue with expression of both neuronal and glial markers, and the lesion was diagnosed as low-grade ganglioglioma.

The etiopathogenesis of pituitary lesions composed of neuronal and adenomatous components remains controversial. The majority of studies have confirmed the common origin of neuronal and adenomatous elements from the same stem/progenitor cells. The presence of focal differentiation of ganglion cells within a neuropil-like background has been documented $[23,43]$. Whether such composite lesions are collision tumours that arise from cells of different histogenesis or the two components are derived from the same cell is a matter of debate. The stem/progenitor cells of normal pituitary, which possess the ability of multidirectional differentiation, are the most likely cells of tumour origin.
Based on these facts, two hypotheses have been put forward. The first reasonable speculation is that the majority of ganglion cell tumours arise as a result of neuronal differentiation within conventional pituitary adenomas, mainly sparsely granulated $\mathrm{GH}$ cell adenoma $[18,21,46]$. This suggestion was confirmed by morphological findings, which demonstrated significant intermixing of adenomatous and gangliocytic elements. Histopathological and immunohistochemical findings documented the presence of cells that exhibit intermediate features between ganglion and $\mathrm{GH}$ or PRL adenoma cells $[4,18,30]$. A close relationship between neurons and adenomatous $\mathrm{GH}$ cells was also confirmed by electron microscopy [3]. Moreover, pituitary hormones have been detected within the neuronal element of some gangliocytic pituitary lesions [25]. Towfighi et al. [46] explained that the transformation of pituitary adenoma cells into mature ganglion cells was a result of their common origin from the same embryonic pituitary cell; their explanation rests on the fact that the cells exhibit features that place them on an intermediate developmental axis between neurons and adenohypophyseal cells. In vitro studies indicated that adenohypophyseal cells cultured in collagen gels might transform spontaneously into neuronal cells [29]. The opposite etiopathogenetic hypothesis suggests that the primary gangliocytoma, which produces $\mathrm{GH}$-releasing hormone $(\mathrm{GHRH})$, is able to stimulate the adenomatous transformation of the adjacent normal pituitary gland. It has been suggested that the intrasellar gangliocytoma might promote the growth of a pituitary adenoma through chronic overstimulation resulting from excess $\mathrm{GHRH}$ production [23].

Considering the common molecular background of pituitary adenoma and ganglion cell tumours, the activation of the mammalian target of rapamycin (mTOR) intracellular pathway and its two main regulators, Akt and Erk, appears to be important. Increased mTOR activity was observed in pituitary adenomas, with the highest frequency in $\mathrm{GH}$-secreting pituitary adenomas. The regulation of MTOR activity was implicated in the treatment of malignant pituitary adenomas and carcinomas [31,41]. Recently, the upregulation of mitogen-activated protein kinase has also been reported in gangliogliomas [37]. Moreover, when the methylation status of O(6)-methylguanine DNA methyltransferase (MGMT) was examined in pituitary adenomas, the degree of MGMT expression appeared to be related 
to therapeutic responses to temozolomide $[1,24,26]$. MGMT protein expression was also implicated as a prognostic factor for patients with low-grade gangliogliomas [11].

Sellar lesions of double morphology, composed of adenoma and ganglion cells, ought to be classified as a mixed/collision pituitary adenoma-gangliocytoma. Our cases document the close morphological relationship between ganglion cells and adenomatous $\mathrm{GH}$-secreting cellular elements. It was suggested recently that in the cases in which the gangliocytic component is closely intermingled with adenoma, the term "pituitary adenoma with gangliocytic component" best emphasizes the clinical importance of the adenomatous parts of the lesion [7].

\section{Conclusions}

Ganglion cell tumours rarely appear in the sellar/ parasellar region, either alone or in combination with pituitary adenoma. A tight mixture of neuronal and adenomatous components is commonly observed. Although the pathogenesis of tumours of such intermingled morphology remains unclear, their origin from the stem/progenitor cells that engender normal pituitary tissue is speculated. Distinguishing both components in sellar lesions as precisely defined individual neoplastic elements may determine the prognosis and direct therapeutic management.

\section{Disclosure}

Authors report no conflict of interest.

\section{References}

1. Arya S, Majaid MA, Shwetha SD, Sravani K, Arivazhagan A, Sampath S, Santosh V. Implications of MGMT methylation status in pituitary adenoma. Pathol Res Pract 2014; 210: 407-411.

2. Asa SL, Bilbao JM, Kovacs K, Linfoot JA. Hypothalamic neuronal hamartoma associated with pituitary growth hormone cell adenoma and acromegaly. Acta Neuropathol 1980; 52: 231-234.

3. Asa SL, Kovacs K, Tindall GT, Barrow DL, Horvath E, Vecsei P. Cushing's disease associated with an intrasellar gangliocytoma producing corticotrophin-releasing factor. Ann Intern Med 1984; 101: 789-793.

4. Asa SL, Scheithauer BW, Bilbao JM, Horvath E, Ryan N, Kovacs K, Randall RV, Laws ER, Jr., Singer W, Linfoot JA, et al. A case for hypothalamic acromegaly: a clinicopathological study of six patients with hypothalamic gangliocytomas producing growth hormone-releasing factor. J Clin Endocrinol Metab 1984; 58: 796-803.

5. Asada H, Otani M, Furuhata S, Inoue H, Toya S, Ogawa Y. Mixed pituitary adenoma and gangliocytoma associated with acromegaly - case report. Neurol Med Chir (Tokyo) 1990; 30 : 628-632.

6. Azarpira N, Pakbaz S, Torabineghad S, Musavi J, Rakei M. Acromegaly associated with mixed pituitary adenoma-gangliocytoma and Rathke's cleft cyst. Turk Neurosurg 2013; 23: 527-530.

7. Balci S, Saglam A, Oruckaptan H, Erbas T, Soylemezoglu F. Pituitary adenoma with gangliocytic component: report of 5 cases with focus on immunoprofile of gangliocytic component. Pituitary 2015; 18: 23-30.

8. Baysefer A, Gezen F, Kayali H, Erdogan E, Timurkaynak E, Celasun B. Intrasellar gangliocytoma resembling pituitary adenoma. Minim Invasive Neurosurg 1997; 40: 107-109.

9. Bodi I, Martin AJ, Connor SE, Thomas NW, Lantos PL. Mixed pituitary gangliocytoma/adenoma (prolactinoma) with histogenetic implications. Neuropathol Appl Neurobiol 2002; 28: 252-255.

10. Bridenstine M, Kerr JM, Lillehei KO, Kleinschmidt-DeMasters BK. Cushing's disease due to mixed pituitary adenoma-gangliocytoma of the posterior pituitary gland presenting with Aspergillus sp. sinus infection. Clin Neuropathol 2013; 32: 377-383.

11. Chang IW, Hsu CT, Lin JW, Hung CH. The prognostic impact of MGMT expression on low-grade gangliogliomas: a clinicopathological and immunohistochemical study. Folia Neuropathol 2013; 51: 275-282.

12. Crowley RK, Al-Derazi Y, Lynch K, Rawluk D, Thompson CJ, Farrell M, Agha A. Acromegaly associated with gangliocytoma. Ir J Med Sci 2012; 181: 353-355.

13. Deng S, Li Y, Guan Y, Xu S, Chen J, Zhao G. Gliomas in the Sellar Turcica Region: A Retrospective Study Including Adult Cases and Comparison with Craniopharyngioma. Eur Neurol 2014; 73: $135-143$

14. Fehn M, Lohmann F, Ludecke DK, Rudorff KH, Saeger W. Ganglioglioma of the neurohypophysis with secretion of vasopressin. Exp Clin Endocrinol Diabetes 1998; 106: 425-430.

15. Finzi G, Cerati M, Marando A, Zoia C, Ferreli F, Tomei G, Castelnuovo P, La Rosa S, Capella C. Mixed pituitary adenoma/craniopharyngioma: clinical, morphological, immunohistochemical and ultrastructural study of a case, review of the literature, and pathogenetic and nosological considerations. Pituitary 2014; 17: 53-59.

16. Fischer EG, Morris JH, Kettyle WM. Intrasellar gangliocytoma and syndromes of pituitary hypersecretion. Case report. J Neurosurg 1983; 59: 1071-1075.

17. Geddes JF, Jansen GH, Robinson SF, Gomori E, Holton JL, Monson JP, Besser GM, Revesz T. 'Gangliocytomas' of the pituitary: a heterogeneous group of lesions with differing histogenesis. Am J Surg Pathol 2000; 24: 607-613.

18. Horvath E, Kovacs K, Scheithauer BW, Lloyd RV, Smyth HS. Pituitary adenoma with neuronal choristoma (PANCH): composite lesion or lineage infidelity? Ultrastruct Pathol 1994; 18: 565-574.

19. Iwase T, Nishizawa S, Baba S, Hinokuma K, Sugimura H, Nakamura S, Uemura K, Shirasawa H, Kino I. Intrasellar neuronal choristoma associated with growth hormone-producing pituitary adenoma containing amyloid deposits. Hum Pathol 1995; 26: 925-928. 
20. Jin G, Hao S, Xie J, Mi R, Liu F. Collision tumors of the sella: coexistence of pituitary adenoma and craniopharyngioma in the sellar region. World J Surg Oncol 2013; 11: 178.

21. Kontogeorgos G, Mourouti G, Kyrodimou E, Liapi-Avgeri G, Parasi E. Ganglion cell containing pituitary adenomas: signs of neuronal differentiation in adenoma cells. Acta Neuropathol 2006; 112: 21-28.

22. Kudo M. Hypothalamic gangliocytoma. Selective appearance of neurofibrillary changes, granulovacuolar degeneration, and argentophilic bodies. Acta Pathol Jpn 1986; 36: 1225-1229.

23. Kurosaki M, Saeger W, Ludecke DK. Intrasellar gangliocytomas associated with acromegaly. Brain Tumor Pathol 2002; 19: 63-67.

24. Lau Q, Scheithauer B, Kovacs K, Horvath E, Syro LV, Lloyd R. MGMT immunoexpression in aggressive pituitary adenoma and carcinoma. Pituitary 2010; 13: 367-379.

25. Li JY, Racadot O, Kujas M, Kouadri M, Peillon F, Racadot J. Immunocytochemistry of four mixed pituitary adenomas and intrasellar gangliocytomas associated with different clinical syndromes: acromegaly, amenorrhea-galactorrhea, Cushing's disease and isolated tumoral syndrome. Acta Neuropatho 1989; 77: 320-328.

26. Liu JK, Patel J, Eloy JA. The role of temozolomide in the treatment of aggressive pituitary tumors. J Clin Neurosci 2015; 22 923-929.

27. Luna V, Morales F, Luengo LM, Sanz A, Diaz J. Pituitary gangliocytoma-adenoma presenting with acromegaly: response to treatment. Arch Intern Med 2001; 161: 1010-1011.

28. Luyken C, Blumcke I, Fimmers R, Urbach H, Wiestler OD, Schramm J. Supratentorial gangliogliomas: histopathologic grading and tumor recurrence in 184 patients with a median follow-up of 8 years. Cancer 2004; 101: 146-155.

29. Martinez-Campos A, Dannies PS. A possible differentiation of anterior pituitary cells in collagen gels into neurons. Cell Tissue Res 1986; 244: 21-26.

30. Mikami S, Kameyama K, Takahashi S, Yoshida K, Kawase T, Sano T, Mukai M. Combined gangliocytoma and prolactinoma of the pituitary gland. Endocr Pathol 2008; 19: 117-121.

31. Monsalves E, Juraschka K, Tateno T, Agnihotri S, Asa SL, Ezzat S, Zadeh G. The PI3K/AKT/mTOR pathway in the pathophysiology and treatment of pituitary adenomas. Endocr Relat Cancer 2014; 21: R331-344.

32. Morikawa M, Tamaki N, Kokunai T, Imai Y. Intrasellar pituitary gangliocyto-adenoma presenting with acromegaly: case report. Neurosurgery 1997; 40: 611-614; discussion 614-615.

33. Moshkin O, Scheithauer BW, Syro LV, Velasquez A, Horvath E, Kovacs K. Collision tumors of the sella: craniopharyngioma and silent pituitary adenoma subtype 3: case report. Endocr Pathol 2009; 20: 50-55.

34. Nishizawa H, Fukuoka H, Iguchi G, Inoshita N, Yamada S, Takahashi Y. AIP mutation identified in a patient with acromegaly caused by pituitary somatotroph adenoma with neuronal choristoma. Exp Clin Endocrinol Diabetes 2013; 121: 295-299.

35. Puchner MJ, Ludecke DK, Saeger W, Riedel M, Asa SL. Gangliocytomas of the sellar region - a review. Exp Clin Endocrinol Diabetes 1995; 103: 129-149.
36. Puchner MJ, Ludecke DK, Valdueza JM, Saeger W, Willig RP, Stalla GK, Odink RJ. Cushing's disease in a child caused by a corticotropin-releasing hormone-secreting intrasellar gangliocytoma associated with an adrenocorticotropic hormone-secreting pituitary adenoma. Neurosurgery 1993; 33: 920-924; discussion 924-925.

37. Rak B, Szlufik S, Grajkowska W, Perek D, Dembowska-Baginska B, Filipek I, Daszkiewicz P, Wlodarski P, Jozwiak J. Upregulation of mitogen-activated protein kinase in ganglioglioma. Folia Neuropathol 2013; 51: 283-289.

38. Rhodes RH, Dusseau JJ, Boyd AS, Jr., Knigge KM. Intrasellar neural-adenohypophyseal choristoma. A morphological and immunocytochemical study. J Neuropathol Exp Neurol 1982; 41: 267-280.

39. Sabel MC, Hans VH, Reifenberger G. Mixed gangliocytoma/ pituitary adenoma. Arch Neurol 2000; 57: 587-588.

40. Saeger W, Puchner MJ, Ludecke DK. Combined sellar gangliocytoma and pituitary adenoma in acromegaly or Cushing's disease. A report of 3 cases. Virchows Arch 1994; 425: 93-99.

41. Sajjad EA, Zielinski G, Maksymowicz M, Hutnik L, Bednarczuk T, Wlodarski P. mTOR is frequently active in $\mathrm{GH}$-secreting pituitary adenomas without influencing their morphopathological features. Endocr Pathol 2013; 24: 11-19.

42. Sato Y, Wada T, Nishikawa Y, Yoshida K, Kurose A, Ogawa A, Ogasawara K. Growth hormone-producing pituitary adenoma regrowing as pituitary adenoma with neuronal choristoma 14 years after tumor removal. World Neurosurg 2013; 80: 436. e11-33.

43. Scheithauer BW, Kovacs K, Randall RV, Horvath E, Okazaki H, Laws ER, Jr. Hypothalamic neuronal hamartoma and adenohypophyseal neuronal choristoma: their association with growth hormone adenoma of the pituitary gland. J Neuropathol Exp Neurol 1983; 42: 648-663.

44. Syro LV, Horvath E, Kovacs K. Double adenoma of the pituitary: a somatotroph adenoma colliding with a gonadotroph adenoma. J Endocrinol Invest 2000; 23: 37-41.

45. Thodou E, Kontogeorgos G, Horvath E, Kovacs K. Prolactin-producing pituitary adenoma with incomplete neuronal transformation: an intermediate adenoma-neuronal tumor. Acta Neuropathol 2004; 108: 115-120.

46. Towfighi J, Salam MM, McLendon RE, Powers S, Page RB. Ganglion cell-containing tumors of the pituitary gland. Arch Pathol Lab Med 1996; 120: 369-377. 